\title{
Essential oil and apple pomace affect fermentation and aerobic stability of alfalfa silage
}

\author{
M. Besharati ${ }^{1 \#}$, V. Palangi ${ }^{2}$, V. Ghozalpour ${ }^{1}$, Z. Nemati ${ }^{1}$ \& T. Ayaşan ${ }^{3 \#}$ \\ ${ }^{1}$ Department of Animal Science, Ahar Faculty of Agriculture and Natural resources, University of Tabriz, Tabriz, Iran. \\ ${ }^{2}$ Department of Animal Science, Agricultural Faculty, Ataturk University, Erzurum, Turkey \\ ${ }^{3}$ Osmaniye Korkut Ata University, Kadirli Academy of Applied Sciences, Osmaniye, Turkey
}

(Received 13 February 2021; Accepted 30 March 2021; Published 31 May 2021)
Copyright resides with the authors in terms of the Creative Commons Attribution 4.0 South African Licence. See: http://creativecommons.org/licenses/by/4.0/za
Condition of use: The user may copy, distribute, transmit and adapt the work, but must recognise the authors and the South African Journal of Animal Science.

\begin{abstract}
This study assessed the effects of the additions of an essential oil (EO), composed of ricinoleic acid, cardol, cardanol, and apple pomace, on fermentation quality and aerobic stability of alfalfa silages. The experimental treatments consisted of T1) alfalfa (control), T2) alfalfa with EO, T3) alfalfa (75\%) with apple pomace $(25 \%), \mathrm{T} 4)$ alfalfa $(75 \%)$ with apple pomace $(25 \%)$ and EO, T5) alfalfa $(50 \%)$ with apple pomace $(50 \%)$, T6) alfalfa $(50 \%)$ with apple pomace $(50 \%)$ and EO, T7) alfalfa $(25 \%)$ with apple pomace $(75 \%)$, and T8) alfalfa (25\%) with apple pomace $(75 \%)$ and EO. The addition of apple pomace decreased the silage $\mathrm{pH}$ compared with the control $(P<0.01)$. Apple pomace at $25 \%$ level increased the total volatile fatty acid (iVFA) content $(P<0.05)$. Essential oil (EO) decreased tVFA and increased dry matter (DM) content 90 days after ensiling $(P<0.01)$. Apple pomace decreased ammonia $\left(\mathrm{N}-\mathrm{NH}_{3}\right)$, crude protein $(\mathrm{CP})$, and crude ash $(\mathrm{CA})$ content and increased the amounts of neutral detergent fibre (NDF) and acid detergent fibre (ADF) ( $P$ $<0.01)$. Essential oil and apple pomace (level $75 \%)$ increased effective digestibility $(P<0.05)$. Apple pomace decreased aerobic stability and the addition of EO increased aerobic stability $(P<0.05)$. Thus, use of apple pomace as a source of fermentable carbohydrate and/or the addition of EO in the preparation of high-quality alfalfa silage is recommended to offset its high buffering capacity and low carbohydrate content.
\end{abstract}

Keywords: cardanol, cardol, ensiling, gas production, in vitro digestibility, ricinoleic acid, silage quality \#Corresponding author: tayasan@gmail.com; m_besharati@hotmail.com

\section{Introduction}

Alfalfa is a valuable forage plant, which is fed to livestock as hay in Iran. However, significant amounts of nutrients are lost from alfalfa in the drying and storage process (Saruhan \& Demirel, 2018). Production of alfalfa silage is attracting increasing attention (Jia et al., 2021), but it is difficult to ensile owing to its high protein level and buffering capacity and low water-soluble carbohydrate content. Therefore, additives must be used during ensiling. Carbohydrate and bacterial additives have been studied for many years to improve the quality of alfalfa silage.

Citrus pulp, tomato pomace, apple pomace, and pistachio pulp are among the by-products from food processing that have been introduced for use in feeding livestock. These materials are produced during seasonal fruit production and are in large part discarded without contaminating the environment (SoycanÖnenç et al., 2015; Besharati et al., 2017). However, these by-products also can be incorporated into silages as a source of fermentable carbohydrate.

Exposure of silage to the air at the time of feeding causes degradation of its quality. Yeasts metabolize lactic acid, and raise the silage pH (Jalc et al., 2010; Turan \& Soycan-Önenç, 2018), and stimulate the growth of harmful microorganisms (Sadeghi et al., 2012; Weiss et al., 2016; Turan \& Soycan-Önenç, 2018). Feeding degraded silage compromises livestock production. The use of additives with protective properties based on their organic acid content could prevent the growth of moulds and yeasts in silage and increase its aerobic stability (Muck et al., 2018).

The antifungal, antibacterial, and antioxidant effects of aromatic plants and their products have prompted attention as dietary supplements. Plants that produce EO have an important place among 
medicinal plants (Sameh et al., 2019; Ali et al., 2020), and have proved to be useful in animal nutrition (Abd El-Mola et al., 2019).

However, there is little information about the effects of EOs on silage fermentation. Therefore, this study was conducted to investigate the effects of an EO on the chemical composition, fermentation quality, and aerobic stability of alfalfa silage. A second objective was to evaluate the addition of apple pomace to alfalfa silage as a source of fermentable carbohydrate.

\section{Materials and Methods}

Alfalfa was harvested at the flowering stage with a dry matter (DM) content of $200 \mathrm{~g} \mathrm{~kg}^{-1}$, chopped to an approximate length of 2 to $2.5 \mathrm{~cm}$, and wilted for 24 hours. An EO containing 30\% ricinoleic acid, 30\% cardol and $20 \%$ cardanol was applied to the forage to achieve final concentrations of $500 \mathrm{mg} \mathrm{EO} \mathrm{kg} \mathrm{silage}^{-1}$ The control silage was treated with an equivalent amount of ethanol.

The treatments consisted of T1) alfalfa silage (control), T2) alfalfa silage with $\left.500 \mathrm{mg} \mathrm{EO} \mathrm{kg}{ }^{-1}, \mathrm{~T} 3\right)$ alfalfa $(75 \%)+$ apple pomace $(25 \%)$ silage, T4) alfalfa $(75 \%)+$ apple pomace $(25 \%)$ silage $+500 \mathrm{mg}$ EO $\left.\mathrm{kg}^{-1}, \mathrm{~T} 5\right)$ alfalfa $(50 \%)+$ apple pomace $(50 \%)$ silage, T6) alfalfa $(50 \%)+$ apple pomace $(50 \%)$ silage +500 $\mathrm{mg} \mathrm{EO} \mathrm{kg}{ }^{-1}$, T7) alfalfa $(25 \%)+$ apple pomace $(75 \%)$ silage; , and T8) alfalfa (25\%) + apple pomace $(75 \%)$ silage $+500 \mathrm{mg} \mathrm{EO} \mathrm{kg}^{-1}$. The silages were ensiled in polyvinyl chloride mini silos $(10 \mathrm{~cm}$ in diameter $\times 90 \mathrm{~cm}$ high, with three replicates per treatment) with a capacity of $3 \mathrm{~kg}$.

After 90 days, silos were opened, and the $\mathrm{pH}$ and dry matter contents of the silages were measured. Samples of each silage were stored at $-20^{\circ} \mathrm{C}$ until the ash, ADF, NDF, and CP contents had been determined (Van Soest et al., 1991; AOAC, 2000) and the in vitro degradation of DM had been measured (Fedorah \& Hrudey, 1983). The fraction of water-soluble carbohydrates was assessed according to Dubois et al. (1956). The concentration of VFA was measured and aerobic stability was determined (Besharati et al., 2020a; 2020b). When the temperature of silage mass reached $2{ }^{\circ} \mathrm{C}$ above ambient, it was considered corrupted (Xu et al., 2019).

No animals were directly used in this research. Rumen fluid from a slaughterhouse was used to assess in vitro gas production. In vitro DM degradation of treatments was measured in three replicate bottles. The percentage of degradability $(\mathrm{Y})$ of DM over time ( $\mathrm{t}$ ) was described by the exponential equation:

$$
Y=a+b\left(1-e^{-c t}\right)
$$

fitted to the data by iterative regression analysis (Palangi \& Macit, 2019; Palangi et al., 2020). The effective degradability (ED) of DM and CP for feedstuffs was estimated as:

$$
E D(\%)=a+b c /(c+k)
$$

In this equation, $\mathrm{k}$ refers to the fractional outflow rate of small particles from the rumen. The value of 0.02 fraction/ $h$ for $k$ was assumed.

Analysis of variance was performed using SAS version 9.1 (SAS Institute Inc., Cary, North Carolina, USA). The mean values were compared using Duncan's test.

\section{Results and Discussion}

The properties and chemical compositions of alfalfa and apple pomace before ensiling are listed in Table 1. The effects of treatments on chemical composition after ensiling for 90 days are shown in Table 2. The addition of apple pomace at a $25 \%$ level increased tVFA content $(P<0.05)$ compared with the control Essential oil decreased tVFA $(p<0.01)$. Additions of $E O$ and apple pomace produced a significant interaction on IVFA $(P<0.01)$. The addition of apple pomace reduced ammonia nitrogen compared with the control $(P$ $<0.01)$.

Table 1 Chemical composition of alfalfa and apple pomace before ensiling

\begin{tabular}{lccccrr}
\hline Feeds & $\begin{array}{c}\text { Dry matter, } \\
\%\end{array}$ & $\mathrm{pH}$ & $\begin{array}{c}\text { Neutral detergent } \\
\text { fibre, \% }\end{array}$ & $\begin{array}{c}\text { Acid detergent } \\
\text { fibre, \% }\end{array}$ & $\begin{array}{c}\text { Water soluble } \\
\text { carbohydrate, \% }\end{array}$ & $\begin{array}{c}\text { Crude } \\
\text { protein, \% }\end{array}$ \\
\hline Alfalfa & 35.0 & 8.4 & 41.80 & 19.46 & 3.8 & 18.02 \\
Apple pomace & 36.0 & 3.5 & 40.42 & 36.64 & 5.2 & 6.12 \\
\hline
\end{tabular}


Table 2 Effect of experimental treatments on chemical composition after ensiling for 90 days (\% DM)

\begin{tabular}{|c|c|c|c|c|c|c|c|c|c|c|}
\hline \multirow{2}{*}{ Treatments } & & \multicolumn{9}{|c|}{ Nutrients } \\
\hline & & DM & $\begin{array}{l}\text { NDF, } \\
\% \mathrm{DM}\end{array}$ & $\begin{array}{l}\text { ADF, } \\
\% \text { DM }\end{array}$ & $\mathrm{pH}$ & $\begin{array}{c}\text { tVFA, } \\
\mathrm{mm}\end{array}$ & $\begin{array}{c}\text { CP, } \\
\text { \%DM }\end{array}$ & $\begin{array}{c}\mathrm{N}-\mathrm{NH}_{3}, \\
\% \mathrm{DM}\end{array}$ & $\begin{array}{c}\text { EE, \% } \\
\text { DM }\end{array}$ & $\begin{array}{c}\text { CA, } \\
\% D M\end{array}$ \\
\hline Apple pomace, \% & EO, mg & & & & & & & & & \\
\hline 0 & 0 & $29.29^{a}$ & $38.09^{b}$ & $20.95^{c}$ & $5.1^{\mathrm{a}}$ & $11.33^{\text {cde }}$ & $14.97^{\mathrm{C}}$ & $70.00^{\mathrm{a}}$ & $4.17^{\mathrm{b}}$ & $10.50^{\mathrm{a}}$ \\
\hline 0 & 500 & $30.70^{\mathrm{a}}$ & $37.92^{b}$ & $21.44^{\mathrm{bc}}$ & $5.1^{\mathrm{a}}$ & $10.33^{\text {ef }}$ & $16.78^{\mathrm{a}}$ & $74.66^{\mathrm{a}}$ & $3.91^{\mathrm{b}}$ & $9.88^{\mathrm{ab}}$ \\
\hline 25 & 0 & $29.70^{\mathrm{ab}}$ & $40.71^{a}$ & $22.80^{\mathrm{b}}$ & $4.2^{\mathrm{b}}$ & $13.33^{\mathrm{ab}}$ & $13.36^{d}$ & $49.00^{b}$ & $2.38^{\mathrm{b}}$ & $8.33^{\mathrm{b}}$ \\
\hline 25 & 500 & $30.70^{\mathrm{a}}$ & $40.26^{a}$ & $21.97^{\mathrm{bc}}$ & $4.2^{\mathrm{b}}$ & $12.66^{\mathrm{abc}}$ & $15.27^{\mathrm{b}}$ & $43.00^{\mathrm{bc}}$ & $2.84^{\mathrm{b}}$ & $8.49^{b}$ \\
\hline 50 & 0 & $29.40^{\mathrm{ab}}$ & $41.05^{\mathrm{a}}$ & $25.24^{\mathrm{a}}$ & $4.1^{\mathrm{c}}$ & $13.66 \mathrm{a}$ & $10.88^{\mathrm{e}}$ & $39.60^{\mathrm{bcd}}$ & $4.49^{b}$ & $5.56^{c}$ \\
\hline 50 & 500 & $32.10^{\mathrm{a}}$ & $41.72^{\mathrm{a}}$ & $26.01^{\mathrm{a}}$ & $4.1^{\mathrm{c}}$ & $9.66^{\dagger}$ & $11.47^{f}$ & $25.66^{\mathrm{e}}$ & $7.46^{\mathrm{a}}$ & $5.98^{c}$ \\
\hline 75 & 0 & $27.10^{\mathrm{b}}$ & $40.87^{\mathrm{a}}$ & $25.63^{\mathrm{a}}$ & $3.8^{\mathrm{d}}$ & $10.66^{\text {def }}$ & $9.36^{9}$ & $28.00^{\mathrm{de}}$ & $4.41^{\mathrm{b}}$ & $3.88^{d}$ \\
\hline 75 & 500 & $31.90^{\mathrm{a}}$ & $40.60^{a}$ & $26.69^{\mathrm{a}}$ & $3.7^{d}$ & $12.00^{\mathrm{bc}}$ & $8.81^{\mathrm{h}}$ & $30.30^{\text {cde }}$ & $4.88^{\mathrm{b}}$ & $5.37^{c d}$ \\
\hline \multicolumn{2}{|l|}{ SE } & 0.47 & 0.63 & 0.51 & 0.03 & 0.51 & 0.25 & 3.87 & 0.94 & 0.54 \\
\hline \multirow[t]{3}{*}{$\mathrm{EO}, \mathrm{mg}$} & 0 & $29.03^{\mathrm{b}}$ & 40.18 & 23.66 & 4.28 & $12.25^{\mathrm{a}}$ & $12.39^{b}$ & 46.66 & 3.86 & 7.31 \\
\hline & 500 & $31.35^{\mathrm{a}}$ & 40.12 & 44279 & 4.25 & $11.16^{\mathrm{b}}$ & $13.08^{\mathrm{a}}$ & 43.16 & 4.77 & 7.44 \\
\hline & SE & 0.40 & 0.31 & 0.26 & 0.02 & 0.26 & 0.01 & 1.93 & 0.47 & 0.27 \\
\hline \multirow[t]{5}{*}{ Apple pomace, \% } & 0 & 30.32 & $38.00^{\mathrm{b}}$ & $21.19^{c}$ & $5.04^{\mathrm{a}}$ & $10.83^{\mathrm{b}}$ & $15.87^{\mathrm{a}}$ & $72.33^{\mathrm{a}}$ & $4.04^{\mathrm{ab}}$ & $10.18^{\mathrm{a}}$ \\
\hline & 25 & 30.19 & $40.41^{\mathrm{a}}$ & $22.39^{b}$ & $4.25^{\mathrm{b}}$ & $13.00^{\mathrm{a}}$ & $14.31^{\mathrm{b}}$ & $45.50^{b}$ & $3.91^{\mathrm{b}}$ & $8.41^{\mathrm{b}}$ \\
\hline & 50 & 30.71 & $41.39^{\mathrm{a}}$ & $25.63^{\mathrm{a}}$ & $4.04^{\mathrm{c}}$ & $11.66^{\mathrm{b}}$ & $11.64^{\mathrm{c}}$ & $32.66^{\mathrm{c}}$ & $5.98^{\mathrm{a}}$ & $6.27^{\mathrm{c}}$ \\
\hline & 75 & 29.55 & $40.74^{\mathrm{a}}$ & $26.16^{\mathrm{a}}$ & $3.72^{d}$ & $11.33^{\mathrm{b}}$ & $9.08^{d}$ & $29.16^{c}$ & $4.64^{\mathrm{a}}$ & $4.62^{d}$ \\
\hline & SE & 0.57 & 0.44 & 0.36 & 0.02 & 0.36 & 0.02 & 2.74 & 0.66 & 0.38 \\
\hline \multicolumn{2}{|c|}{ Analysis of variance summary } & \multicolumn{9}{|c|}{$P$-values } \\
\hline \multicolumn{2}{|c|}{ Essential oil } & 0.001 & 0.900 & 0.319 & 0.201 & 0.008 & $<0,001$ & 0.219 & 0.188 & 0.754 \\
\hline \multicolumn{2}{|c|}{ Apple pomace } & 0.556 & $<0.001$ & $<0.001$ & $<0.001$ & 0.004 & $<0.001$ & $<0.001$ & 0.018 & $<0.001$ \\
\hline \multicolumn{2}{|c|}{ Interaction } & 0.087 & 0.813 & 0.299 & 0.325 & 0.009 & $<0.001$ & 0.097 & 0.362 & 0.225 \\
\hline
\end{tabular}

DM: dry matter, CP: crude protein, EE: ether extract, CA: crude ash, NDF: neutral detergent fibre, ADF: acid detergent fibre, tVFA: total volatile fatty acids, AP: apple pomace effect

$a, b, c$ within a column, means with a common superscript did not differ with probability $P=0.05$

The $\mathrm{pH}$ of the silages with $25 \%, 50 \%$ and $75 \%$ apple pomace was lower than that of the control $(P$ $<0.01)$. However, the EO treatment did not affect the $\mathrm{pH}$ of the silages $(P>0.05)$. Dry matter was higher in silages that were augmented with EO $(P<0.05)$. The addition of apple pomace increased NDF and ADF compared with the control $(P<0.05)$. Ammonia content was decreased as the level of apple pomace in the silage was increased $(P<0.05)$. The addition of apple pomace to alfalfa silage decreased aerobic stability compared with control and other experimental treatments (Figure 1). Aerobic stability was increased in treatments with $\mathrm{EO}$ additive compared with the control $(P<0.05)$.

The outcomes of the current experiment agree with those of others that investigated the effects of carbohydrate sources on silages (Hashemzadeh-Cigari et al., 2011; Besharati et al., 2020c). Guler et al. (2006) observed reduced $\mathrm{pH}$ and increased lactic acid concentration by adding apple pomace at $5 \%$ and $10 \%$ to alfalfa silage without affecting DM content. Kung et al. (2008) used Crina ${ }^{\circledR}$ (thymol, eugenol, vanillin, and limonene) to modify silage fermentation. They reported that the $\mathrm{pH}$ of the silage augmented with this additive did not differ from that of the control group, which was consistent with the present findings. The addition of peppermint and mint EOs at 120 and $240 \mathrm{mg}$ decreased the $\mathrm{pH}$ of corn silage, but other EOs did not have an effect (Hodjatpanah-Montazeri et al., 2016).

In the present experiment, tVFA was increased in the silages with $25 \%$ and $50 \%$ apple pomace compared with the control $(P<0.05)$. Abdollahzadeh \& Abdulkarimi $(2012)$ reported an increase in tVFA in silage containing either apple pomace or tomato pomace compared with the control. Other researchers who investigated the effects of carbohydrate sources on silages (Islam et al., 2001; Aksu et al., 2006; Khan et al., 2006) reported increased amounts of tVFA. The addition of apple pomace reduced $\mathrm{N}-\mathrm{NH}_{3}$ compared with the 
control $(P<0.05)$. Rodrigues et al. (2008) observed a significant decrease in gas production during in vitro digestion resulting from increased amounts of straw in apple pomace-straw mixtures. Yang et al. (2010) also reported that adding apple pomace to alfalfa silage reduced the amount of $\mathrm{N}-\mathrm{NH}_{3}$ significantly compared with control. By inhibiting proteolysis in silage, apple pomace probably decreased non-protein nitrogen and $\mathrm{N}-\mathrm{NH}_{3}$ compared with control. However, Guler et al. (2006) did not observe any changes in $\mathrm{N}^{-\mathrm{NH}_{3}}$ production by adding apple pomace to alfalfa silage. The $\mathrm{EO}$ additive did not affect $\mathrm{N}-\mathrm{NH}_{3}$, which was consistent with Kung et al.'s (2008) findings. Hodjatpanah-Montazeri et al. (2016) reported that EO of cinnamon at 120 and 240 $\mathrm{mg} / \mathrm{kg}$ had no effect on $\mathrm{N}-\mathrm{NH}_{3}$ in corn silage. However, in the same study, oregano and thyme $\mathrm{EO}$ and peppermint at the lower level decreased $\mathrm{N}-\mathrm{NH}_{3}$ content compared with control.

Treating alfalfa silage with EO produced no effect on the amounts of NDF and ADF compared with control in this experiment. In contrast, Hodjatpanah-Montazeri et al. (2016) found apple pomace and EO additives increased ADF significantly compared with control $(P<0.05)$. Rodrigues et al. $(2008)$ showed that adding straw to apple pomace increased its ADF content significantly.

Hodjatpanah-Montazeri et al. (2016) observed that peppermint and oregano EOs at 120 and 240 $\mathrm{mg} / \mathrm{kg}$ alfalfa silage increased the CP content of corn silage compared with control, which is consistent with the results of the current experiment. In contrast, Chavez et al. (2012) found no change in the level of CP by adding oregano EO to silage.

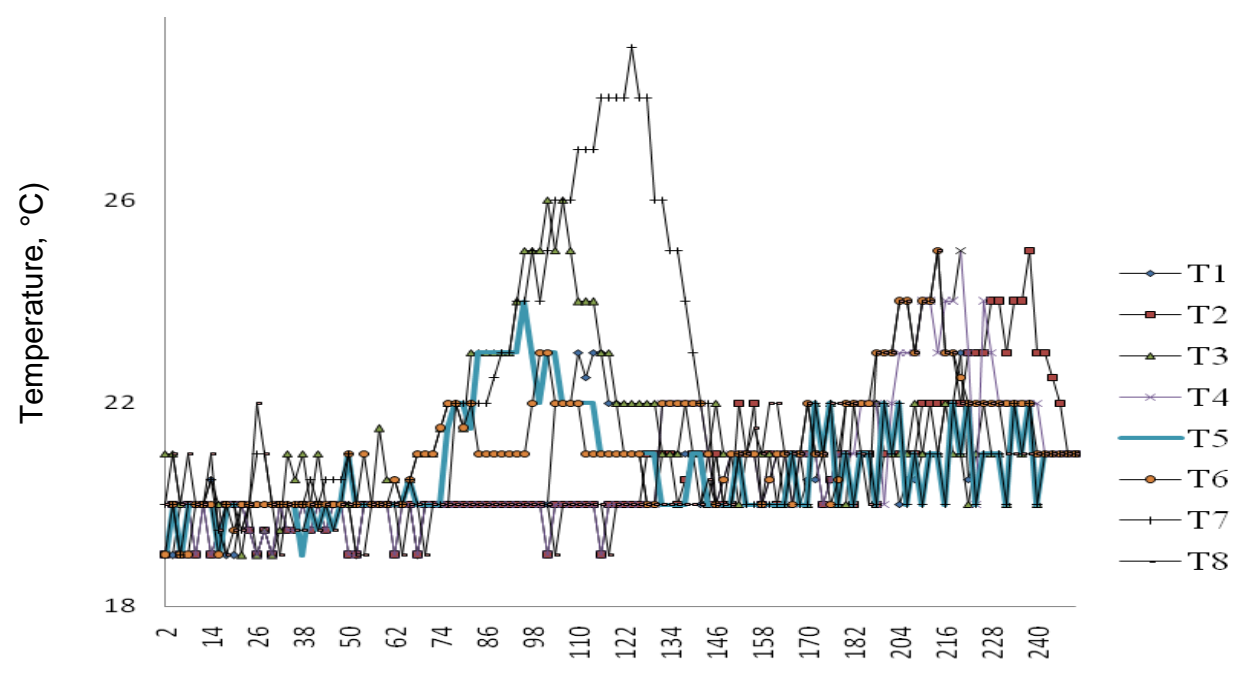

Aerobic exposure time, hours)

Figure 1 Silage temperature during hours of aerobic exposure

T1: alfalfa silage without additives, T2: alfalfa silage + $500 \mathrm{mg}$ essential oil/ $\mathrm{kg}$, T3: alfalfa (75\%) + apple pomace (25\%) silage, T4: alfalfa $(75 \%)+$ apple pomace $(25 \%)$ silage $+500 \mathrm{mg}$ essential oil/kg, T5: alfalfa $(50 \%)+$ apple pomace $(50 \%)$ silage, T6: alfalfa $(50 \%)+$ apple pomace $(50 \%)$ silage $+500 \mathrm{mg}$ essential oil/kg, T7: alfalfa(25\%) + apple pomace (75\%) silage, T8: alfalfa(25\%) + apple pomace (75\%) silage + 500 mg essential oil/kg

The interaction of the level of apple pomace effects and the addition of EO consistently affected the parameter estimates of the exponential equation describing DM degradation of the silages $(P<0.001)$. The EO treatment decreased the soluble and very rapidly degradable fractions of the DM $(a)$ in the silages with $25 \%$ or less apple pomace, had the opposite effect in the silage that contained $50 \%$ apple pomace and had no effect on (a) for the $75 \%$ apple pomace silage. Adding the EO to the silage without apple pomace greatly increased the insoluble but potentially degradable component (b) but had no effect on the silages that contained apple pomace. The fractional rate constant (c) was altered by the use of EO only in the silage containing $75 \%$ apple pomace. 
Table 3 Effects of treatments on in vitro DM degradability of alfalfa silage augmented with apple pomace and essential oil

\begin{tabular}{|c|c|c|c|c|c|c|}
\hline \multirow{2}{*}{\multicolumn{2}{|c|}{ Silage }} & \multirow{2}{*}{ Additive } & \multicolumn{4}{|c|}{ Parameter estimates } \\
\hline & & & $a, \%$ & $b, \%$ & c, \%/hour & ED, \% \\
\hline \multicolumn{2}{|c|}{$0 \%$ apple pomace } & $0 \mathrm{mg}$ EO & $16.53^{b}$ & $24.98^{d}$ & $0.097^{\mathrm{a}}$ & $37.25^{\text {def }}$ \\
\hline \multicolumn{2}{|c|}{$0 \%$ apple pomace } & $500 \mathrm{mg}$ EO & $11.96^{\mathrm{c}}$ & $41.32^{\mathrm{a}}$ & $0.010^{\mathrm{a}}$ & $39.41^{\mathrm{bcd}}$ \\
\hline \multicolumn{2}{|c|}{$25 \%$ apple pomace } & $0 \mathrm{mg}$ EO & $12.49^{\mathrm{c}}$ & $32.96^{\mathrm{b}}$ & $0.061^{\mathrm{bc}}$ & $36.40^{\text {ef }}$ \\
\hline \multicolumn{2}{|c|}{$25 \%$ apple pomace } & $500 \mathrm{mg}$ EO & $7.75^{\mathrm{d}}$ & $33.32^{\mathrm{b}}$ & $0.086^{\mathrm{ab}}$ & $34.75^{\dagger}$ \\
\hline \multicolumn{2}{|c|}{$50 \%$ apple pomace } & $0 \mathrm{mg} \mathrm{EO}$ & $10.87^{\mathrm{c}}$ & $35.78^{\mathrm{ab}}$ & $0.062^{\mathrm{bc}}$ & $37.95^{\text {cde }}$ \\
\hline \multicolumn{2}{|c|}{$50 \%$ apple pomace } & $500 \mathrm{mg}$ EO & $17.20^{\mathrm{b}}$ & $32.09^{b c}$ & $0.067^{\mathrm{bc}}$ & $40.57^{\mathrm{bc}}$ \\
\hline \multicolumn{2}{|c|}{$75 \%$ apple pomace } & $0 \mathrm{mg}$ EO & $22.02^{\mathrm{a}}$ & $26.30^{c d}$ & $0.054^{c}$ & $41.18^{\mathrm{ab}}$ \\
\hline \multicolumn{2}{|c|}{$75 \%$ apple pomace } & $500 \mathrm{mg}$ EO & $23.36^{\mathrm{a}}$ & $24.42^{d}$ & $0.093^{\mathrm{a}}$ & $43.44^{\mathrm{a}}$ \\
\hline \multicolumn{3}{|l|}{ SE } & 0.57 & 2.01 & 0.008 & 0.87 \\
\hline \multirow[t]{3}{*}{$P$-values } & \multicolumn{2}{|l|}{ Essential oil } & 0.326 & 0.608 & 0.648 & 0.044 \\
\hline & \multicolumn{2}{|c|}{ Apple pomace } & $<.0001$ & 0.001 & 0.647 & $<.0001$ \\
\hline & \multicolumn{2}{|l|}{ Interaction } & $<0.001$ & $<0.001$ & $<0.001$ & 0.082 \\
\hline
\end{tabular}

a: soluble and rapidly degradable component, $b$ : insoluble but potentially degradable component, c: constant fractional rate; ED: effective degradability

a,b,c,d,e,f Within a column, means with a common superscript did not differ with probability $P=0.05$

The inclusion of apple pomace with alfalfa has been shown to diminish aerobic stability of silage possibly as a consequence of higher soluble carbohydrate and lactic acid contents (Ke et al., 2015). Yang et al. (2010) demonstrated that the addition of apple pomace to alfalfa silage reduced aerobic stability and observed that it could be because of loss of nutrients and DM during storage. Aerobic stability was increased in the treatments with EO compared with control, which may be because of the antimicrobial activity and inhibitory effects of some EOs that prevent spoilage of silage by inhibiting deamination and proteolysis (Hodjatpanah-Montazeri et al., 2016). Adding two EOs to barley silage increased aerobic stability compared with the control treatment, which agreed with data of the present study (Chaves et al., 2012). HodjatpanahMontazeri et al. (2016) observed increased aerobic stability of silage with the addition of various EOs to corn silage. The addition of a combination of EOs to modify the fermentation of corn silage did not affect yeast, fungi, and Enterobacteria owing to aerobic stability compared with the control treatment (Da Silva et al., 2018). In areas with high apple production, where most of the crop is used in processing factories, apple pomace is produced in large quantities and disposal of the by-products can result in environmental pollution. The use of apple pomace in the preparation of silage as feed for livestock in these areas could reduce environmental pollution and reduce feed costs.

\section{Conclusion}

The addition of EO improved the DM and CP content of silage and increased its effective degradability. Aerobic stability was enhanced in treatments with an EO. The use of a carbohydrate source as a fermentable dry matter for bacterial population and/or an EO additive is necessary to offset the deficiencies of alfalfa for making high quality silage.

\section{Authors' Contributions}

MB supervised the experiment, and ZN advised the project. MN conducted the laboratory analyses. TA and VP supervised the experiment and finalized the manuscript.

\section{Conflict of Interest Declaration}

The authors declare there are no conflicts of interest.

\section{References}

Abd El-Mola, A.M., El-Bordeny, N.E., Azzaz, H.H. \& Al Zahar, H., 2019. Effect of some aromatic plants by products on the in vitro rumen fermentation and buffalo's milk production in early lactation. Egyptian J. Nut. Feed. 22(1), 2331. https://doi.org/10.21608/ejnf.2019.75836 
Abdollahzadeh, F. \& Abdulkarimi, R., 2012. The effects of some agricultural by-products on ruminal fermentation and apparent digestibility of Holstein dairy cows. Life Sci. J. 9(4), 270-274.

Aksu, T., Baytok, E., Karsli, M.A. \& Muruz, H., 2006. Effects of formic acid, molasses and inioculant additives on corn silage composition, organic matter digestibility and microbial protein synthesis in sheep. Small Rum. Res. 61, 2933. https://doi.org/10.1016/j.smallrumres.2004.12.013

Ali, M., Latif, A., Zaman, K., Mehsud, S., Akbar, N., Ahmad, M. \& Arfan, M., 2020. Evaluation of antioxidant and antimicrobial activities on various extracts of Himalayan medicinal plants. Pakistan J. Pharm Sci. 33(2), 695-703.

AOAC 2000. Official methods of analysis. 17th edition. Association of Official Analytical Chemists, Inc., Arlington, Virginia, USA.

Besharati, M., Palangi, V., Niazifar, M. \& Nemati, Z., 2020c. Comparison study of flaxseed, cinnamon and lemon seed essential oils additives on quality and fermentation characteristics of lucerne silage. Acta Agric, Slovenica. 115(2), 455-462. https://doi.org/10.14720/aas.2020.115.2.1483

Besharati, M., Shafipour, N., Abdi, E. \& Nemati, Z., 2017. Effects of supplementation alfalfa silage with molasses, orange pulp and Lactobacillus buchneri on in vitro dry matter digestibility and gas production. J. Biosci. Biotechnol. 6(1), 43-47.

Besharati, M., Karimi, M., Taghizadeh, A., Nemati, Z. \& Kaygisiz, A., 2020a. Improve quality of alfalfa silage ensiled with orange pulp and bacterial additive. J. Agric. Nat. 23(6), 1669-1677. https://doi.org/10.18016/ksutarimdoga.vi.673623

Besharati, M., Palangi, V., Moaddab, M., Nemati, Z., Pliego, A.B. \& Salem, A.Z., 2020b. Influence of cinnamon essential oil and monensin on ruminal biogas kinetics of waste pomegranate seeds as a biofriendly agriculture environment. Waste and Biomass Valorization 12, 2333-342. https://doi.org/10.1007/s12649-020-01167-2

Chaves, A.V., Baah, J., Wang, Y., McAllistera, T.A. \& Benchaar, C., 2012. Effects of cinnamon leaf, oregano and sweet orange essential oils on fermentation and aerobic stability of barley silage. J. Sci. Food Agric. 92, 906-915. https://doi.org/10.1002/jsfa.4669

Da Silva, N.C., Nascimento, C.F., Nascimento, F.A., de Resende, F.D., Daniel, J.L.P. \& Siqueira, G.R., 2018. Fermentation and aerobic stability of rehydrated corn grain silage treated with different doses of Lactobacillus buchneri or a combination of Lactobacillus plantarum and Pediococcus acidilactici. J. Dairy Sci. 101(5), 41584167. https://doi.org/10.3168/jds.2017-13797

Dubois, M., Giles, K.A., Hamilton, J.K., Rebes, P.A. \& Smith, F. 1956 Colorimetric method for determination of sugars and related substances. Analytical Chemistry 28, 350-356. https://doi.org/10.1021/ac60111a017

Fedorah, P.M. \& Hrudey, S.E., 1983. A simple apparatus for measuring gas production by methanogenic culture in serum bottles. Environ Technol Let 4, 425-432. https://doi.org/10.1080/09593338309384228

Guler, T., Çerçi, I.H., Çiftçi, M. \& Ertas, O.N., 2006. Can apples be used as a source of fermentable carbohydrate when making alfalfa silage. Revue Méd. Vét. 157(3), 163-167.

Hashemzadeh-Cigari, F., Khorvash, M., Ghorbani, G.R. \& Taghizadeh, A., 2011. The effects of wilting, molasses and inoculants on the fermentation quality and nutritive value of lucerne silage. S. Afr. J. Anim. Sci. 41(4), 377-388.

Hodjatpanah-Montazeri, M., Danesh Mesgaran, N. \& Vakili, A., 2016. Effect of essential oils of various plants as microbial modifier to alter corn silage fermentation and in vitro methane production. Iranian J. Appl Anim. Sci. 6(2), 269-276.

Islam, M., Enishi, O., Purnomoadi, A., Higuchi, K., Takusari, N. \& Terada, F., 2001. Energy and protein utilization by goats fed Italian ryegrass silage treated with molasses, urea, cellulase or cellulase + lactic acid bacteria. Small Rum Res. 42, 49-60. https://doi.org/10.1016/S0921-4488(01)00235-8

Jia, T., Wang, B., Yu, Z. \& Wu, Z., 2021. The effects of stage of maturity and lactic acid bacteria inoculants on the ensiling characteristics, aerobic stability and in vitro digestibility of whole-crop oat silages. Grassland Science 67, 55-62. https://doi.org/10.1111/grs.12285

Ke, W.C., Yang, F.Y., Undersander, D.J. \& Guo, X.S., 2015. Fermentation characteristics, aerobic stability, proteolysis and lipid composition of alfalfa silage ensiled with apple or grape pomace. Anim. Feed Sci. Technol. 202, 12-19. https://doi.org/10.1016/j.anifeedsci.2015.01.009

Khan, M.A., Sarwar, M., Nisa, M., Iqbal, Z., Khan, M.S., Lee, W.S., Lee, H.J. \& Kim, H.S., 2006. Chemical composition, in situ digestion kinetics and feeding value of oat grass (Avena sativa) ensiled with molasses for Nili-Ravi buffaloes. Asian-Australas. J. Anim. Sci. 19, 1127-1133. https://doi.org/10.5713/ajas.2006.1127

Kung, L.Jr., Williams, P., Schmidt, R.J. \& Hu, W., 2008. A blend of essential plant oils used as an additive to alter silage fermentation or used as a feed additive for lactating dairy cows. J. Dairy Sci. 91, 4793-4800. https://doi.org/10.3168/jds.2008-1402

Muck, R.E., Nadeau, E.M.G., McAllister, T.A., Contreras-Govea, F.E., Santos, M.C. \& Kung, Jr L., 2018. Silage review: Recent advances and future uses of silage additives. J. Dairy Sci. 101(5), 3980-4000. https://doi.org/10.3168/jds.2017-13839

Palangi, V. \& Macit, M., 2019. In situ crude protein and dry matter ruminal degradability of heat-treated barley. Rev Méd Vét. 170, 123-128.

Palangi, V., Macit, M. \& Bayat, A.R., 2020. Mathematical models describing disappearance of lucerne hay in the rumen using the nylon bag technique. S. Afr. J. Anim. Sci. 50(5), 719-725. DOI: 10.4314/sajas.v50i5.9

Rodrigues, M.A.M., Guedes, C.M., Rodrigues, A.L., Cone, J.W., Van Gelder, A.H., Ferreira, L.M.M., Santos, A.S. \& Sequeira, C.A., 2008. Evaluation of the nutritive value of apple pulp mixed with different amounts of wheat straw. Livestock Res. Rural Develop. 20(1), 1-10. 
Sadeghi, K., Khorvash, M., Ghorbani, G.R., Forouzmad, M.A., Boroumand, M. \& Hashemzadeh-Cigari, F., 2012. Effects of homo-fermentative bacterial inoculants on fermentation characteristics and nutritive value of low dry matter corn silage. Iranian J. Vet. Res. 13(4), 41-51.

Sameh, S., Al-Sayed, E., Labib, R.M. \& Singab, A.N.B., 2019. Comparative metabolic profiling of essential oils from Spondias pinnata (Linn. F.) Kurz and characterization of their antibacterial activities. Ind. Crops and Products 137, 468-474. https://doi.org/10.1016/j.indcrop.2019.05.060

Saruhan, V. \& Demirel, R., 2018. Quality improvements of alfalfa (Medicago sativa L.) silage using ensiled pear (Pyrus communis L.) as carbohydrate source. Fresen Environ Bul. 27(4), 2562-2566.

Soycan-Önenç, S., Koc, F., Coşkuntuna, L., Özdüven, M. \& Gümüş, T. 2015. The effect of oregano and cinnamon essential oils on fermentation quality and aerobic stability of field pea silages. Asian-Australas. J. Anim. Sci. 28(9), 1281-1287. https://doi.org/10.5713/ajas.15.0122

Steel, R.G. \& Torrie, J.H. 1980. Principles and procedures of statistics: A biometrical approach. McGraw Hill, New York, USA. P. 481.

Turan, A. \& Soycan-Önenç, S., 2018. Effect of cumin essential oil usage on fermentation quality, aerobic stability and in vitro digestibility of alfalfa silage. Asian-Australas. J. Anim. Sci. 31(8), 1252-1258. https://doi.org/10.5713/ajas.17.0834

Van Soest, P.J,, Robertson, J.B. \& Lewis, B.A., 1991. Methods of dietary fiber, neutral detergent fiber, and non-starch polysaccharides in relation to animal nutrition. J. Dairy Sci. 74, 3583-3597. https://doi.org/10.3168/jds.S00220302(91)78551-2

Weiss, K., Kroschewski, B. \& Auerbach, H., 2016. Effects of air exposure, temperature and additives on fermentation characteristics, yeast count, aerobic stability and volatile organic compounds in corn silage. J. Dairy Sci. 99(10), 8053-8069. https://doi.org/10.3168/jds.2015-10323

Xu, S., Yang, J., Qi, M., Smiley, B., Rutherford, W., Wang, Y. \& McAllister, T.A., 2019. Impact of Saccharomyces cerevisiae and Lactobacillus buchneri on microbial communities during ensiling and aerobic spoilage of corn silage. J. Anim. Sci. 97(3), 1273-1285. https://doi.org/10.1093/jas/skz021

Yang, W.Z., Ametaj, B.N., Benchaar, C. \& Beauchemin, K.A., 2010. Dose response to cinnamaldehyde supplementation in growing beef heifers: Ruminal and intestinal digestion. J. Anim. Sci. 88, 680-688. https://doi.org/10.2527/jas.2008-1652 